\title{
Ionic palladium complex as an efficient and recyclable catalyst for the carbonylative Sonogashira reaction
}

\author{
Da Yang, Dongliang Wang, Huan Liu, Xiaoli Zhao, Yong Lu, Shijun Lai \#, Ye Liu* \\ Shanghai Key Laboratory of Green Chemistry and Chemical Processes, School of Chemistry and Molecular Engineering, East China Normal University, \\ Shanghai 200062, China
}

A R T I C L E I N F 0

Article history:

Received 2 November 2015

Accepted 23 November 2015

Published 5 March 2016

\section{Keywords:}

Ionic phosphine ligand

Palladium complex

Carbonylative Sonogashira reaction

Ionic liquid

\begin{abstract}
A B S T R A C T
The neutral palladium(II) complex bis-[1-(5'-diphenylphosphinothiazol-2'-yl)-imidazolyl] dichloropalladium(II) (1A) ligated by thiazolylimidazolyl-based phosphine (L1) in which thiazolylimidazolyl acted as an S- and $\mathrm{N}$-donor provider with weak coordinating nature, and the ionic complex bis-[1-(5'-diphenylphosphinothiazol-2'-yl)-3-methylimidazolium] dichloropalladium(II) trifluoromethanesulfonate (2A) ligated by thiazolylimidazolium-based phosphine (L2) after quaternization of $\mathbf{L 1}$ using methyl trifluoromethanesulphonate were synthesized. It was found that the introduced positive charges and strong electron-withdrawing effect in $2 \mathrm{~A}$ not only led to changes in the configuration and structural stability of the complex, but also lowered its catalytic performance in carbonylative Sonogashira reactions. These effects reveal the important role of the N-donor in 1A. In addition, as an ionic palladium complex, $\mathbf{2 A}$ combined with the room-temperature ionic liquid 1-butyl-3-methylimidazolium hexafluorophosphate could be recycled eight times as the catalyst in carbonylative Sonogashira reactions without detectable metal leaching.
\end{abstract}

(C) 2016, Dalian Institute of Chemical Physics, Chinese Academy of Sciences. Published by Elsevier B.V. All rights reserved.

\section{Introduction}

Among aromatic carbonyl compounds, $\alpha, \beta$-alkynones are important structural motifs in many bioactive molecules and intermediates for the synthesis of natural products and pharmaceuticals [1-4]. In general, $\alpha, \beta$-alkynones have been prepared by the coupling of alkyne organometallic reagents with acid chlorides in the presence of transition metal reagents [5-9]. Unfortunately, this methodology is limited with respect to functional group tolerance, substrate stability, reaction conditions (dry solvent under an inert atmosphere), atom economy, and environmental friendliness. Since they were first reported by Tanaka's group [10] in 1981, palladium (Pd)-catalyzed carbonylative Sonogashira reactions have become an alternative approach to synthesize $\alpha, \beta$-alkynones. In carbonylative Sonogashira reactions, $\mathrm{CO}$ acts as an important $\mathrm{C} 1$ building block to introduce carbonyl group into the parent molecules. Many researchers have modified and improved this methodology, including $\mathrm{Wu}$ et al. [11] for homogeneous carbonylative Sonogashira reactions and other groups [12-14] for heterogeneous ones. It is widely accepted that the involved ligands can greatly tailor the catalytic performance of homogenous Pd complex catalysts through electronic and steric effects [15-19]. However, these catalysts still suffer from the problems of difficult product separation, rapid activity loss, and non-recyclability $[11,20,21]$.

Non-volatile ionic liquids (ILs) have been recognized as promising alternative solvents to immobilize homogenous pal-

\footnotetext{
* Corresponding author. Tel: +86-21-62232078; Fax: +86-21-62233424; E-mail: yliu@chem.ecnu.edu.cn

\# Corresponding author. Tel: +86-21-62232078; Fax: +86-21-62233424; E-mail: laishijun@126.com

This work was supported by the National Natural Science Foundation of China $(21473058,21273077)$.

DOI: 10.1016/S1872-2067(15)61022-1 | http://www.sciencedirect.com/science/journal/18722067 | Chin. J. Catal., Vol. 37, No. 3, March 2016
} 
ladium catalysts, preventing their leaching and deactivation [22]. ILs can be functionalized with phosphine ligands, and the resulting phosphine-functionalized ILs have been investigated as ionic complexes (catalysts) and used in combination with room-temperature ionic liquids (RTILs) to immobilize homogenous catalysts [23-27]. Because the melting points of phosphine-functionalized ILs are usually higher than $100{ }^{\circ} \mathrm{C}$, they are typically defined as ionic phosphines. It has also been found that when phosphines are introduced into ILs to obtain ionic phosphines, the positive charges of ILs with strong electron-withdrawing character dramatically influence the coordinating ability of the involved phosphines and in turn the properties of the corresponding transition metal complexes in terms of structure and catalytic activity [27,28].

Herein, the neutral monophosphine L1 (1-(5'-diphenylphosphinothiazol-2'-yl)-imidazolyl) and its ionic counterpart L2 (1-(5'-diphenylphosphinothiazol-2'-yl)-3-methylimidazolium trifluoromethanesulfonate) reported by us previously [29] were complexed with $\mathrm{PdCl}_{2}\left(\mathrm{CH}_{3} \mathrm{CN}\right)_{2}$ to afford the neutral Pd(II) complex bis-[1-(5'-diphenylphosphinothiazol-2'-yl)-imidazolyl] dichloropalladium(II) (1A) and an ionic complex bis-[1-(5'-diphenylphosphinothiazol-2'-yl)-3-methylimidazoliu m] dichloropalladium(II) trifluoromethanesulfonate (2A) (Scheme 1). The effects of the positive charge in $\mathbf{L} 2$ on the coordination ability of the involved phosphine, the structure of the corresponding Pd complex, and the catalytic performance of the complexes in the carbonylative Sonogashira reaction are discussed (Scheme 2). In addition, 2A can be regarded as an ionic Pd complex that is compatible with RTILs, so its recyclability in 1-butyl-3-methylimidazolium hexafluorophosphate $\left([\mathrm{Bmim}] \mathrm{PF}_{6}\right)$ is investigated.

\section{Experimental}

\subsection{Reagents and analysis}

L1 and L2 were first prepared according to our previously published method [29]. Other chemical reagents were purchased from Shanghai Aladdin Chemical Reagent Co. Ltd. and Shanghai Alfa Aesar, China, and used as received. Diethyl ether was distilled from sodium. DMF was dried over $\mathrm{CaSO}_{4}$ and distilled before use. Both diethyl ether and DMF were stored over $4 \AA$ molecular sieves under $\mathrm{N}_{2} .{ }^{1} \mathrm{H},{ }^{31} \mathrm{P}$, and ${ }^{13} \mathrm{C}$ NMR spectra were recorded on a Bruker ARX 400 spectrometer $(400 \mathrm{MHz})$ at room temperature. ${ }^{31} \mathrm{P}$ NMR spectra were referenced to $85 \%$ $\mathrm{H}_{3} \mathrm{PO}_{4}$ sealed in a capillary tube as an internal standard. CHN elemental analysis was performed on a Vario EL III Elemental Analyzer. The amount of Pd in the organic phase was quantified by inductively coupled plasma atomic emission spectrometry

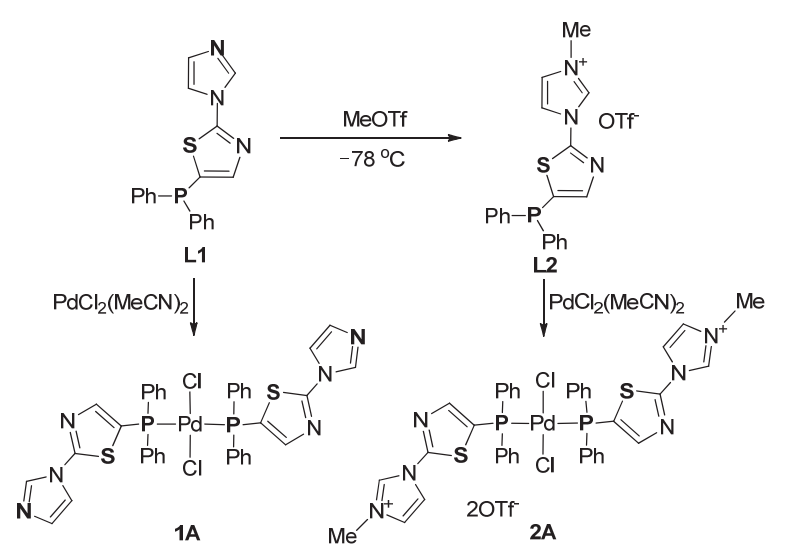

Scheme 1. Formation of complexes $\mathbf{1 A}$ and $2 A$ from ligands $\mathbf{L 1}$ and L2, respectively.

(ICP-AES) on an IRIS Intrepid II XSP instrument (Thermo Electron Corporation). Gas chromatography (GC) was performed on a Shimadzu-2014 equipped with a DM-Wax capillary column $(30 \mathrm{~m} \times 0.25 \mathrm{~mm} \times 0.25 \mu \mathrm{m})$. GC-mass spectrometry (GC-MS) was recorded on an Agilent 6890 spectrometer equipped with an Agilent 5973 mass selective detector. Purification of the compounds was carried out by flash chromatography on silica gel.

\subsection{Synthesis of catalysts}

\subsubsection{Synthesis of complex $\mathbf{1 A}$}

Under $\mathrm{N}_{2}$ atmosphere, $\mathbf{L 1}(0.13 \mathrm{~g}, 0.4 \mathrm{mmol})$ dissolved in dry $\mathrm{CH}_{2} \mathrm{Cl}_{2}(4 \mathrm{~mL})$ was added to a solution of $\mathrm{PdCl}_{2}\left(\mathrm{MeCN}_{2}\right.$ (0.05 g, $0.2 \mathrm{mmol}$ ) in dry $\mathrm{CH}_{2} \mathrm{Cl}_{2}(8 \mathrm{~mL})$. The mixture was stirred vigorously at room temperature for $3 \mathrm{~h}$. The solvent was removed under vacuum using a rotary evaporator. The obtained yellow solid residue was washed with diethyl ether and dried under vacuum to give the product $\mathbf{1 A}$ in $97 \%$ yield. A sample suitable for single-crystal X-ray diffraction (XRD) analysis was obtained by slow volatilization of a $\mathrm{CH}_{2} \mathrm{Cl}_{2}$ solution containing 1A. ${ }^{1} \mathrm{H}$ NMR $\left(\delta, \mathrm{CD}_{2} \mathrm{Cl}_{2}\right): 8.23$ (s, $\left.2 \mathrm{H}, \mathrm{NCHN}\right)$, 7.55-7.75 (m, 24H), $7.21(\mathrm{~s}, 2 \mathrm{H}) ;{ }^{13} \mathrm{C}$ NMR $\left(\delta, \mathrm{CD}_{2} \mathrm{Cl}_{2}\right): 164.43(\mathrm{~s}$, NCN), 151.17 (s), 135.69 (s), 134.25 (s), 131.70 (s), 131.05 (s), 128.67 (s), 128.23 (s), 121.70 (s), 117.62 (s); 31P NMR ( $\delta$, $\mathrm{CD}_{2} \mathrm{Cl}_{2}$ ): $10.80\left(\mathrm{~s}, \mathrm{PPh}_{2}\right)$. CHN (\%) elemental analysis for $\mathbf{1 A}$ $\left(\mathrm{C}_{36} \mathrm{H}_{28} \mathrm{Cl}_{2} \mathrm{~N}_{6} \mathrm{P}_{2} \mathrm{Pd}_{1} \mathrm{~S}_{2}, 848.0\right):$ C 50.82, H 3.43, N 9.96 (Calcd. C 50.99, H 3.33, N 9.91).

\subsubsection{Synthesis of complex $\mathbf{2 A}$}

Under $\mathrm{N}_{2}$ atmosphere, $\mathbf{L} 2(0.250 \mathrm{~g}, 0.50 \mathrm{mmol})$ dissolved in dry $\mathrm{CH}_{2} \mathrm{Cl}_{2}(3 \mathrm{~mL})$ was added to a solution of $\mathrm{PdCl}_{2}\left(\mathrm{MeCN}_{2}\right.$ $(0.065 \mathrm{~g}, 0.25 \mathrm{mmol})$ in dry $\mathrm{CH}_{2} \mathrm{Cl}_{2}(7 \mathrm{~mL})$. The mixture was

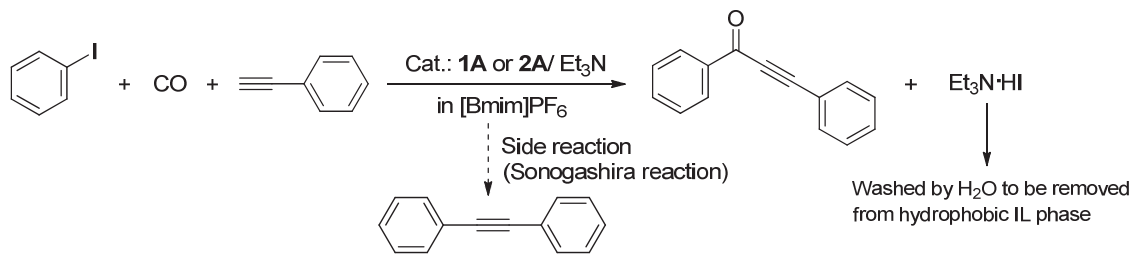

Scheme 2. Carbonylative Sonogashira reaction of iodobenzene with phenylacetylene catalyzed by $\mathbf{1 A}$ and $\mathbf{2 A}$. 
stirred vigorously at room temperature for $3 \mathrm{~h}$. The collected yellow solid precipitate was washed with diethyl ether and dried under vacuum to give the product $2 \mathrm{~A}$ with a yield of $86 \%$. A sample suitable for single-crystal XRD analysis was obtained by slow volatilization of a $\mathrm{CH}_{2} \mathrm{Cl}_{2}$ solution containing $2 \mathrm{~A} .{ }^{1} \mathrm{H}$ $\operatorname{NMR}\left(\delta, \mathrm{CD}_{2} \mathrm{Cl}_{2}\right): 9.93(\mathrm{~s}, 2 \mathrm{H}, \mathrm{NCHN}), 8.39(\mathrm{t}, 2 \mathrm{H}, J=2 \mathrm{~Hz}), 8.04$ $(\mathrm{t}, 2 \mathrm{H}, J=2 \mathrm{~Hz}), 7.77-7.83(\mathrm{~m}, 10 \mathrm{H}), 7.65-7.69(\mathrm{~m}, 4 \mathrm{H})$, $7.58-7.63(\mathrm{~m}, 8 \mathrm{H}), 4.23\left(\mathrm{~s}, 6 \mathrm{H}, 2 \mathrm{CH}_{3}\right) ;{ }^{13} \mathrm{C} \mathrm{NMR}\left(\delta, \mathrm{CD}_{3} \mathrm{CN}\right)$ : 160.80 (s, NCN), 150.61 (s), 135.80 (s), 134.33 (t, $J=27 \mathrm{~Hz}$ ), $132.54(\mathrm{~s}), 132.19(\mathrm{~s}), 128.99(\mathrm{t}, J=22.5 \mathrm{~Hz}), 127.60(\mathrm{q}, J=$ $117.5 \mathrm{~Hz}, \mathrm{CF}_{3}$ ), 125.22 (s), 122.40 (s), 120.73 (s), 36.77 (s, $\mathrm{CH}_{3}$ ); 31P NMR $\left(\delta, \mathrm{CD}_{2} \mathrm{Cl}_{2}\right): 11.8\left(\mathrm{~s}, \mathrm{PPh}_{2}\right)$. CHN (\%) elemental analysis of $2 \mathrm{~A}\left(\mathrm{C}_{40} \mathrm{H}_{34} \mathrm{Cl}_{2} \mathrm{~F}_{6} \mathrm{~N}_{6} \mathrm{O}_{6} \mathrm{P}_{2} \mathrm{Pd}_{1} \mathrm{~S}_{4}, 1176.2\right)$ : C 40.76, H 2.97, N 7.19 (Calcd. C 40.84, H 2.91, N 7.14).

\subsubsection{Preparation of phosphine selenides}

Phosphine selenides were prepared by the reactions of phosphines L1, L2, and $\mathrm{PPh}_{3}$ with $30 \mathrm{mg}$ selenium $\left(7.63 \%{ }^{77} \mathrm{Se}\right)$ with a molar ratio of $1: 1$ in $\mathrm{CDCl}_{3}$ at $50{ }^{\circ} \mathrm{C}$ for $24 \mathrm{~h}$. The selenides were directly analyzed without isolation by a Bruker Avance 500 spectrometer at ambient temperature.

\subsection{X-ray crystallography}

Intensity data for $\mathbf{1 A}$ and $\mathbf{2 A}$ were collected at $25{ }^{\circ} \mathrm{C}$ on a Bruker SMART APEX II diffractometer using graphite-monochromated Mo- $K_{\alpha}$ radiation $(\lambda=0.071073 \mathrm{~nm})$. Data reduction included absorption correction by the multi-scan method. The structures were solved by direct methods and refined by full-matrix least-squares using SHELXS-97 (Sheldrick, 1990), with all non-hydrogen atoms refined anisotropically. Hydrogen atoms were added at their geometrically ideal positions and refined isotropically. The crystal data and refinement details are given in Table 1.

\subsection{General procedure for carbonylative Sonogashira reaction}

In a typical experiment, the isolated crystalline precatalyst 1A (or 2A, $0.005 \mathrm{mmol}$ ) was sequentially mixed with $3 \mathrm{~mL}$ of solvent (DMF or $\left[\mathrm{Bmim}_{\mathrm{P}} \mathrm{PF}_{6}\right.$ if required), iodobenzene (5 mmol), phenylacetylene $(6 \mathrm{mmol})$, and $\mathrm{Et}_{3} \mathrm{~N}(7.5 \mathrm{mmol})$. The obtained mixture was placed in a sealed Teflon-lined stainless steel autoclave, purged with syngas (CO, 1.0 MPa) and then stirred vigorously at the required temperature for the appointed time. Upon completion of the reaction, the mixture was cooled to room temperature and the pressure was carefully released. The reaction mixture was extracted with diethyl ether $(5 \mathrm{~mL} \times 3)$. The ether fractions were combined and then analyzed by GC to determine the conversion of PhI (1-dodecane as an internal standard) and the selectivity for the carbonylative products (normalization method). The structures of the carbonylative products were further confirmed by GC-MS.

In the recycling experiments, the remaining slurry containing 2A, $\left[\mathrm{Bmim} \mathrm{PF}_{6}\right.$, and the formed ammonium salt $\left(\mathrm{Et}_{3} \mathrm{~N} \cdot \mathrm{HI}\right)$ after ether extraction was used directly without further treatment for the next run unless otherwise specified. In specified cases, the formed ammonium salt $\left(\mathrm{Et}_{3} \mathrm{~N} \cdot \mathrm{HI}\right)$ was removed by
Table 1

Crystal data and structure refinement for $\mathbf{1 A}$ and $\mathbf{2 A}$.

\begin{tabular}{lcc}
\hline Item & $\mathbf{1 A}$ & $\mathbf{2 A}$ \\
\hline Empirical formula & $\mathrm{C}_{36} \mathrm{H}_{28} \mathrm{Cl}_{2} \mathrm{~N}_{6} \mathrm{P}_{2} \mathrm{Pd}_{1} \mathrm{~S}_{2}$ & $\mathrm{C}_{38} \mathrm{H}_{34} \mathrm{Cl}_{2} \mathrm{~N}_{6} \mathrm{P}_{2} \mathrm{Pd}_{1} \mathrm{~S}_{2} \cdot$ \\
Formula mass & & $2\left(\mathrm{C}_{1} \mathrm{~F}_{3} \mathrm{~S}_{1} \mathrm{O}_{3}\right)$ \\
Crystal system & 848.00 & 1176.21 \\
Space group & Triclinic & Monoclinic \\
$a(\mathrm{~nm})$ & $P-1$ & $P 2_{1} / c$ \\
$b(\mathrm{~nm})$ & $1.02543(13)$ & $1.4322(2)$ \\
$c(\mathrm{~nm})$ & $1.16366(15)$ & $1.9177(3)$ \\
$\alpha\left({ }^{\circ}\right)$ & $1.6126(2)$ & $0.90143(13)$ \\
$\beta\left({ }^{\circ}\right)$ & $81.525(4)$ & 90 \\
$\gamma\left({ }^{\circ}\right)$ & $74.388(4)$ & $100.888(5)$ \\
$\left.V(\mathrm{~nm})^{3}\right)$ & $83.266(4)$ & 90 \\
$Z$ & $1.8269(4)$ & $2.4313(6)$ \\
$d_{\text {calc }}\left(\mathrm{Mg} / \mathrm{m}^{3}\right)$ & 2 & 2 \\
$\mu\left(\right.$ Mo- $\left.K_{\alpha}\right)(\mathrm{mm})$ & 1.542 & 1.607 \\
$T\left({ }^{\circ} \mathrm{C}\right)$ & 0.892 & 0.803 \\
$\lambda(\mathrm{nm})$ & $23(2)$ & $23(2)$ \\
Total reflections & 0.071073 & 0.071073 \\
Unique reflections $\left(R_{\text {int }}\right)$ & 20959 & 28184 \\
$R_{1}[I>2 \sigma(I)]$ & $6400(0.0911)$ & $4288(0.0821)$ \\
$w R_{2}($ all data) & 0.0603 & 0.0417 \\
$F(000)$ & 0.1815 & 0.0973 \\
Goodness-of-fit on $F^{2}$ & 856 & 1184 \\
& 0.995 & 1.038 \\
\hline & &
\end{tabular}

washing the slurry with water $(3 \mathrm{~mL})$. The remaining IL phase was then collected for reuse. Because of the stoichiometric consumption of the base, $\mathrm{Et}_{3} \mathrm{~N}(7.5 \mathrm{mmol})$ was added to each reaction. All manipulations were conducted in air.

\section{5. ${ }^{1} \mathrm{H}$ and ${ }^{13} \mathrm{C}$ NMR data for the products listed in Table 3}

1,3-Diphenylprop-2-yn-1-one (Table 3, entry 1$).{ }^{1} \mathrm{H}$ NMR $(\delta$, $\left.\mathrm{CDCl}_{3}\right): 8.23(\mathrm{~d}, 2 \mathrm{H}, J=7.2 \mathrm{~Hz}), 7.65-7.68(\mathrm{~m}, 2 \mathrm{H}), 7.59-7.63(\mathrm{~m}$, $1 \mathrm{H}), 7.45-7.52(\mathrm{~m}, 3 \mathrm{H}), 7.38-7.42(\mathrm{~m}, 2 \mathrm{H}) ;{ }^{13} \mathrm{C} \mathrm{NMR}\left(\delta, \mathrm{CDCl}_{3}\right)$ : 178.08 (s, C=0), 136,89 (s), 134.18 (s), 133.12 (s), 130.85 (s), 129.62 (s), 128.73 (s), 128.67 (s), 120.14 (s), 93.16 (s), 86.91 (s).

3-Phenyl-1-(o-tolyl)prop-2-yn-1-one (Table 3, entry 2). ${ }^{1 \mathrm{H}}$ $\operatorname{NMR}\left(\delta, \mathrm{CDCl}_{3}\right): 8.31(\mathrm{~d}, 2 \mathrm{H}, J=8.8 \mathrm{~Hz}), 7.65-7.67(\mathrm{~m}, 2 \mathrm{H})$, $7.35-7.49(\mathrm{~m}, 5 \mathrm{H}), 7.28(\mathrm{~d}, 1 \mathrm{H}, J=7.2 \mathrm{~Hz}), 2.68\left(\mathrm{~s}, 3 \mathrm{H}, \mathrm{CH}_{3}\right) ;{ }^{13} \mathrm{C}$ NMR ( $\left.\delta, \mathrm{CDCl}_{3}\right): 179.78$ (s, C=0), $140.54(\mathrm{~s}), 140.54$ (s), 135.70 (s), 133.24 (s), 132.96 (s), 132.21 (s), 130.63 (s), 128.67 (s), 125.92 (s), 120.35 (s), 91.87 (s), 88.38 (s), 22.02 (s, $\mathrm{CH}_{3}$ ).

3-Phenyl-1-(m-tolyl)prop-2-yn-1-one (Table 3, entry 3). ${ }^{1} \mathrm{H}$ $\operatorname{NMR}\left(\delta, \mathrm{CDCl}_{3}\right): 8.04(\mathrm{t}, 2 \mathrm{H}, J=6.8 \mathrm{~Hz}), 7.68-7.70(\mathrm{~m}, 2 \mathrm{H})$, 7.39-7.51 (m, 5H), $2.45\left(\mathrm{~s}, 3 \mathrm{H}, \mathrm{CH}_{3}\right) ;{ }^{13} \mathrm{C} \mathrm{NMR}\left(\delta, \mathrm{CDCl}_{3}\right): 178.28$ (s, C=0), 138.53 (s), 136.91 (s), 135.03 (s), 133.09 (s), 130.79 (s), 129.81 (s), 128.71 (s), 128.55 (s), 127.16 (s), 120.22 (s), $92.91(\mathrm{~s}), 87.03(\mathrm{~s}), 21.38\left(\mathrm{~s}, \mathrm{CH}_{3}\right)$.

3-Phenyl-1-( $p$-tolyl)prop-2-yn-1-one (Table 3, entry 4). ${ }^{1} \mathrm{H}$ $\operatorname{NMR}\left(\delta, \mathrm{CDCl}_{3}\right): 8.12(\mathrm{~d}, 2 \mathrm{H}, J=8 \mathrm{~Hz}), 7.67-7.70(\mathrm{~m}, 2 \mathrm{H})$, 7.47-7.51 (m, 1H), 7.40-7.44 (m, 2H), $7.32(\mathrm{~d}, 1 \mathrm{H}, J=8 \mathrm{~Hz})$, $2.45\left(\mathrm{~s}, 3 \mathrm{H}, \mathrm{CH}_{3}\right) ;{ }^{13} \mathrm{C} \mathrm{NMR}\left(\delta, \mathrm{CDCl}_{3}\right): 177.78(\mathrm{~s}, \mathrm{C}=0), 145.26$ (s), 134.61 (s), 133.07 (s), 130.72 (s), 129.75 (s), 129.38 (s), 




Fig. 1. ${ }^{31} \mathrm{P}$ NMR spectra (162 MHz) of the selenides of $\mathbf{L 1}, \mathbf{L 2}$, and $\mathrm{PPh}_{3}$.

128.69 (s), 120.27 (s), 92.64 (s), 86.94 (s), 21.89 (s, $\left.\mathrm{CH}_{3}\right)$.

1-(4-Methoxyphenyl)-3-phenylprop-2-yn-1-one (Table 3, entry 5$).{ }^{1} \mathrm{H}$ NMR $\left(\delta, \mathrm{CDCl}_{3}\right): 8.18-8.22(\mathrm{~m}, 2 \mathrm{H}), 7.67-7.69(\mathrm{~m}$, 2H), 7.40-7.52 (m, 3H), 6.97-7.01 (m, 2H), $3.91\left(\mathrm{~s}, 3 \mathrm{H}, \mathrm{CH}_{3}\right) ;{ }^{13} \mathrm{C}$ $\operatorname{NMR}\left(\delta, \mathrm{CDCl}_{3}\right): 176.63$ (s, C=0), 164.50 (s), 132.99 (s), 131.93 (s), 130.62 (s), 130.22 (s), 128.68 (s), 120.36 (s), 113.91 (s), $92.24(\mathrm{~s}), 86.93(\mathrm{~s}), 55.64\left(\mathrm{~s}, \mathrm{CH}_{3}\right)$.

1-(2-Methoxyphenyl)-3-phenylprop-2-yn-1-one (Table 3, entry 6). ${ }^{1} \mathrm{H}$ NMR $\left(\delta, \mathrm{CDCl}_{3}\right): 8.10\left(\mathrm{dd}, 1 \mathrm{H}, J_{1}=2 \mathrm{~Hz}, J_{2}=7.6 \mathrm{~Hz}\right)$, 7.62-7.65 (m, 2H), 7.53-7.57 (m, 1H), 7.38-7.48 (m, 3H), 7.01-7.08 (m, 2H), $3.97\left(\mathrm{~s}, 3 \mathrm{H}, \mathrm{CH}_{3}\right) ;{ }^{13} \mathrm{C} \mathrm{NMR}\left(\delta, \mathrm{CDCl}_{3}\right): 176.81$ (s, C=0), 159.84 (s), 135.11 (s), 133.00 (s), 132.74 (s), 130.51 (s), 128.63 (s), 126.66 (s), 120.67 (s), 120.33 (s), 112.20 (s), 91.65(s), 89.19 (s), $55.96\left(\mathrm{~s}, \mathrm{CH}_{3}\right)$.

3-Phenyl-1-(4-(trifluoromethyl)phenyl)prop-2-yn-1-one (Table 3, entry 7). ${ }^{1} \mathrm{H}$ NMR $\left(\delta, \mathrm{CDCl}_{3}\right): 8.33(\mathrm{~d}, 2 \mathrm{H}, J=8 \mathrm{~Hz}), 7.79$ $(\mathrm{d}, 2 \mathrm{H}, J=8 \mathrm{~Hz}), 7.69-7.71(\mathrm{~m}, 2 \mathrm{H}), 7.50-7.54(\mathrm{~m}, 1 \mathrm{H})$, 7.42-7.46 (m, 2H); ${ }^{13} \mathrm{C}$ NMR $\left(\delta, \mathrm{CDCl}_{3}\right): 176.76$ (s, C=0), 139.35 (s), $133.17\left(\mathrm{q}, \mathrm{CF}_{3}, J=130 \mathrm{~Hz}\right), 133.25$ (s), 131.25 (s), 128.83 (s), 125.73 (q, J = $14.8 \mathrm{~Hz}), 124.91$ (s), 122.20 (s), 119.64 (s), $94.52(\mathrm{~s}), 86.58(\mathrm{~s})$.

1-(3-Nitrophenyl)-3-phenylprop-2-yn-1-one (Table 3, entry 9). ${ }^{1} \mathrm{H} \mathrm{NMR}\left(\delta, \mathrm{CDCl}_{3}\right): 9.06(\mathrm{t}, 1 \mathrm{H}, J=2 \mathrm{~Hz}), 8.48-8.54(\mathrm{~m}, 2 \mathrm{H})$,
7.72-7.78 (m, 3H), 7.53-7.57 (m, 1H), 7.45-7.49 (m, 2H); ${ }^{13} \mathrm{C}$ $\operatorname{NMR}\left(\delta, \mathrm{CDCl}_{3}\right)$ : 175.48 (s, C=0), $148.48(\mathrm{~s}), 138.13(\mathrm{~s}), 134.62$ (s), 133.38 (s), 131.48 (s), 129.98 (s), 128.89 (s), 128.18 (s), 124.50 (s), 119.39 (s), 95.33 (s), 86.25 (s).

3-Phenyl-1-(thiophen-2-yl)prop-2-yn-1-one (Table 3, entry 10). ${ }^{1} \mathrm{H}$ NMR $\left(\delta, \mathrm{CDCl}_{3}\right): 8.04(\mathrm{~d}, 1 \mathrm{H}, J=3.5 \mathrm{~Hz}), 7.75(\mathrm{~d}, 1 \mathrm{H}, J=$ $4.5 \mathrm{~Hz}$ ), 7.69 (d, 2H, $J=7 \mathrm{~Hz}), 7.51(\mathrm{t}, 1 \mathrm{H}, J=7 \mathrm{~Hz}), 7.45(\mathrm{t}, 2 \mathrm{H}, J$ $=7 \mathrm{~Hz}), 7.22(\mathrm{t}, 1 \mathrm{H}, J=4.5 \mathrm{~Hz}) ;{ }^{13} \mathrm{C} \operatorname{NMR}\left(\delta, \mathrm{CDCl}_{3}\right): 169.80(\mathrm{~s}$, $\mathrm{C}=0$ ), 144.97 (s), 135.26 (s), 135.10 (s), 133.06 (s), 130.88 (s), 128.73 (s), 128.37 (s), 119.95 (s), 91.75 (s), 86.53 (s).

1-Nitro-4-(phenylethynyl)benzene (Table 3 , entry 11). ${ }^{1} \mathrm{H}$ $\operatorname{NMR}\left(\delta, \mathrm{CDCl}_{3}\right): 8.20(\mathrm{~d}, 2 \mathrm{H}, J=8.8 \mathrm{~Hz}), 7.65(\mathrm{~d}, 2 \mathrm{H}, J=8.8 \mathrm{~Hz})$, 7.54-7.58 (m, 2H), 7.37-7.40 (m, 3H); ${ }^{13} \mathrm{C}$ NMR $\left(\delta, \mathrm{CDCl}_{3}\right)$ : 147.00 (s, C=0), 132.28 (s), 131.87 (s), 130.27 (s), 129.31 (s), 128.57 (s), 123.65 (s), 122.13 (s), $94.74(\mathrm{~s}), 87.59(\mathrm{~s})$.

\section{Results and discussion}

It was believed that the introduction of a positive charge with strong electron-withdrawing ability into L1 to afford L2 would change the coordination ability of the corresponding phosphines. According to the method reported in Refs. [30-32], the values of ${ }^{1} \mathrm{~J}_{\mathrm{Se}-\mathrm{P}}$ in the ${ }^{77} \mathrm{Se}$ isotopomer of the corresponding phosphine selenides in ${ }^{31} \mathrm{P}$ NMR spectra can be used to evaluate the $\sigma$-donor ability of a phosphine. As shown in Fig. 1, after replacement of one phenyl group in $\mathrm{PPh}_{3}\left({ }^{1} J_{\text {Se-P }}=729 \mathrm{~Hz}\right)$ with thiazolylimidazolyl, the phosphine obtained using $\mathbf{L} \mathbf{1}$ exhibited an increased value of ${ }^{1} J_{\mathrm{Se}-\mathrm{P}}(744 \mathrm{~Hz})$. This indicates an increase in the $\pi$-acceptor ability (i.e., weaker $\sigma$-donor ability) originating from the relatively stronger electron-withdrawing ability of thiazolylimidazolyl than that of a phenyl group. Compared with $\mathbf{L 1}$ and $\mathrm{PPh}_{3}$, the highest ${ }^{1} J_{\mathrm{Se}-\mathrm{P}}$ value $(768 \mathrm{~Hz})$ was observed for L2 because of the intense electron-withdrawing effect resulting from the positively charged thiazolylimidazolium ring on the phosphine fragment.

The different coordinating ability of $\mathbf{L 1}$ and $\mathbf{L} 2$ affected the structural parameters of the corresponding Pd complexes 1A and 2A, as depicted in Fig. 2. Both $\mathbf{1 A}$ and 2A possessed typical square-planar geometry, which is structurally similar to trans- $\mathrm{PdCl}_{2}\left(\mathrm{PPh}_{3}\right)_{2}$ [33]. The $\mathrm{Pd}(\mathrm{II})\left(d^{8}\right)$ center, lying at the
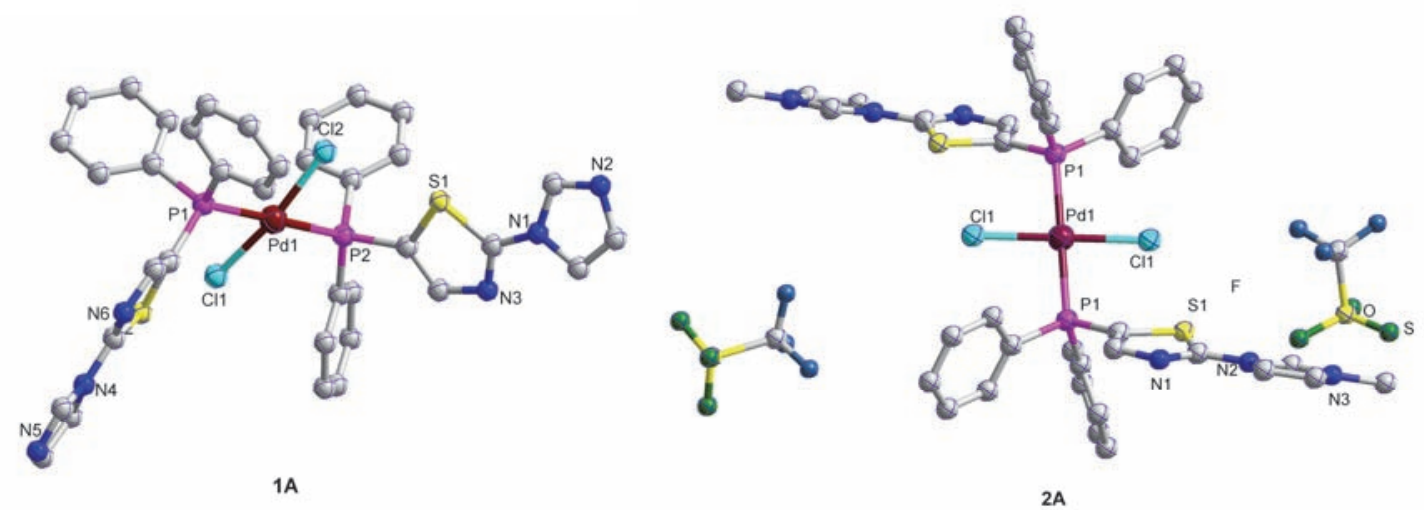

Fig. 2. Single crystal structures of $\mathbf{1 A}$ and $\mathbf{2 A}$. Hydrogen atoms and solvent molecules have been omitted for clarity. Selected bond distances (nm) and angles ( ${ }^{\circ}$ ): 1A, Pd1-P1 0.2329(2), Pd1-P2 0.2326(2), Pd1-Cl1 0.2281(2), Pd1-Cl2 0.2295(2); P1-Pd1-P2 179.48(9), Cl1-Pd1-Cl2 170.23(1); 2A, Pd1-P1 0.23316(1), Pd1-Cl1 0.22851(1); P1-Pd1-P2 180.0, Cl1-Pd1-Cl2 180.0. Interplanar dihedral angle $\left(\theta,\left({ }^{\circ}\right)\right)$ between thiazolyl and imidazolyl rings: 1A, 1.671(3), 14.685(3); 2A, both 13.303(2). 
center of inversion, was coordinated by two chloride ions and two phosphines in trans positions. However, 1A possessed distorted square-planar geometry, whereas ideal square-planar geometry with complete anti-symmetry was observed for $\mathbf{2 A}$ because the repulsive force of the two positive charges made the two pendant thiazolylimidazolium groups move apart as far as possible. The bond distances of Pd-P in $\mathbf{1 A}(0.2329(2)$, and $0.2326(2) \mathrm{nm})$ are slightly shorter than that in $\mathbf{2 A}(0.23316(1)$ $\mathrm{nm})$, indicating the higher structural stability of $\mathbf{1 A}$ compared with $2 \mathbf{A}$. In $\mathbf{1 A}$, the interplanar dihedral angles $(\theta)$ between the thiazolyl imidazolyl rings are $1.671(3)^{\circ}$ and $14.685(3)^{\circ}$ in comparison with those in $\mathbf{2 A}$ (both $13.303(2)^{\circ}$ ), which further indicates the torsional configuration of $\mathbf{1 A}$.

Because of their different structures, the catalytic performance of the Pd complexes was also varied dramatically. The carbonylative coupling of phenylacetylene with iodobenzene under $\mathrm{CuI}$-free conditions was selected as a model reaction to evaluate the catalytic performance of $\mathbf{1 A}$ and $\mathbf{2 A}$; the results are summarized in Table 2. DMF was selected as the optimal solvent after screening DMF, THF, toluene, and acetone over 1A. With the same Pd concentration ( $0.1 \mathrm{~mol} \%), 1 \mathrm{~A}$ exhibited higher activity (turnover frequency (TOF) of $840 \mathrm{~h}^{-1}$ ) than that of $2 \mathrm{~A}$ and $\mathrm{PdCl}_{2}\left(\mathrm{PPh}_{3}\right)_{2}$ under mild reaction conditions $\left(90^{\circ} \mathrm{C}, 1\right.$ $\mathrm{h}$, and $p(\mathrm{CO})=1.0 \mathrm{MPa}$ ) (entries 1 vs. 2 and 3 ). When the reaction temperature was increased from 90 to $120^{\circ} \mathrm{C}$, a very high TOF of $3560 \mathrm{~h}^{-1}$ was obtained over $\mathbf{1 A}$ when Pd concentration was decreased to $0.05 \mathrm{~mol} \%$ (entry 4 ). Under the same conditions, a relatively lower TOF of $2960 \mathrm{~h}^{-1}$ was obtained over 2A (entry 5). As observed in Fig. 1, the phosphine fragments in L1, L2, and $\mathrm{PPh}_{3}$ exhibited the $\sigma$-donor ability (electron-rich character $)$ in the order of $\mathrm{PPh}_{3}\left({ }^{1} J_{\mathrm{Se}-\mathrm{P}}=729 \mathrm{~Hz}\right)>\mathbf{L 1}\left({ }^{1} \mathrm{Je}_{\mathrm{Se}} \mathrm{P}=744 \mathrm{~Hz}\right)$ $>\mathbf{L 2}\left({ }^{1} \mathrm{~J}_{\mathrm{Se}-\mathrm{P}}=768 \mathrm{~Hz}\right)$. However, the catalytic efficiency over A1, A2, and $\mathrm{PdCl}_{2}\left(\mathrm{PPh}_{3}\right)_{2}$ displayed the order: $\mathbf{A 1}\left(\mathrm{TOF}=840 \mathrm{~h}^{-1}\right)>$ $\mathrm{PdCl}_{2}\left(\mathrm{PPh}_{3}\right)_{2}\left(\mathrm{TOF}=770 \mathrm{~h}^{-1}\right)>\mathbf{A 2}\left(\mathrm{TOF}=71 \mathrm{~h}^{-1}\right)$, which was not consistently correlated to the $\sigma$-donor ability of the involved phosphines. It was noted that, compared with $\mathrm{PPh}_{3}, \mathbf{L 1}$ contains additional coordination sites at S- and N-donor atoms besides that of the common phosphine fragment. Therefore, the available N,S-donors of the weak coordinating ligands in 1A are believed to be able to temporarily associate with Pd center to provide additional protection for the active $\mathrm{Pd}$ catalyst against deactivation and then dissociate to provide an unsaturated site for the subsequent insertion of the reaction substrate, which gave rise to the high activity of $\mathbf{1 A}$. As for $\mathbf{2 A}$ and $\mathrm{PdCl}_{2}\left(\mathrm{PPh}_{3}\right)_{2}$,

Table 2

Carbonylative Sonogashira coupling of iodobenzene with phenylacetylene catalyzed by different Pd complexes.

\begin{tabular}{lccccrc}
\hline Entry & $\begin{array}{c}\text { Pd complex } \\
(\mathrm{mmol})\end{array}$ & $\begin{array}{c}\text { Pd conc. } \\
(\mathrm{mol} \%)\end{array}$ & $\begin{array}{c}\text { Time } \\
(\mathrm{h})\end{array}$ & $\begin{array}{c}\text { Conv. } \\
(\%)\end{array}$ & $\begin{array}{r}\text { Sel. a } \\
(\%)\end{array}$ & $\begin{array}{r}\text { TOF } \\
\left(\mathrm{h}^{-1}\right)\end{array}$ \\
\hline 1 & $\mathbf{1 A}$ & 0.1 & 1.0 & 85 & 99 & 840 \\
2 & $\mathbf{2 A}$ & 0.1 & 1.0 & 75 & 100 & 710 \\
3 & $\mathrm{PdCl}_{2}\left(\mathrm{PPh}_{3}\right)_{2}$ & 0.1 & 1.0 & 78 & 99 & 770 \\
4 b & $\mathbf{1 A}$ & 0.05 & 0.5 & 89 & 100 & 3560 \\
5 b & $\mathbf{2 A}$ & 0.05 & 0.5 & 74 & 100 & 2960 \\
\hline
\end{tabular}

the absence of $\mathrm{N}$-donor atoms meant that the active Pd catalyst was unable to be protected effectively, leading to the depressed activity of these catalysts compared with that of $\mathbf{1 A}$.

The scope of the reaction catalyzed by $\mathbf{1 A}$ was then examined (Table 3). The electronic effect and steric hindrance of the aryl substituents of the aryl iodides obviously affected the reaction rate. Because of the competing Sonogashira reaction, the corresponding side-products of aryl-substituted internal acetylenes were found universally but in very low yields. However, when 1-bromo-4-nitrobenzene was used in parallel, the carbonylative Sonogashira coupling barely proceeded. Conversely, when $\mathrm{CO}$ was replaced with $\mathrm{N}_{2}$, the Sonogashira cross-coupling occurred smoothly under the same reaction conditions. This suggests that the active $\mathrm{Pd}^{0}$ species formed in $\mathrm{N}_{2}$ atmosphere exhibited higher oxidative addition ability than that of the $\mathrm{Pd}^{0}$-CO species formed in $\mathrm{CO}$ atmosphere toward the substrates, especially aryl bromides with low reactivity.

Ionic complex $2 \mathbf{A}$ could be used as a catalyst with the RTIL

\section{Table 3}

Generality of $\mathbf{1 A}$ as a precatalyst for the carbonylative Sonogashira coupling of aryl halides with phenylacetylene in DMF.

\begin{tabular}{|c|c|c|c|c|}
\hline Entry & Aryl halide & Product $^{a}$ & Conv. ${ }^{\mathrm{b}}(\%)$ & Yield ${ }^{b}(\%)$ \\
\hline 1 & & & 95 & 99 (1) \\
\hline 2 & & & 99 & $100(0)$ \\
\hline 3 & & & 96 & 99 (1) \\
\hline 4 & & & 93 & $99(1)$ \\
\hline 5 & & & 86 & 99 (1) \\
\hline 6 & & & 79 & $98(2)$ \\
\hline 7 & & & 98 & $97(3)$ \\
\hline 8 & & & 100 & $90(10)$ \\
\hline 9 & & & 100 & \\
\hline 10 & & & 100 & 99 (1) \\
\hline 11 & & & - & $-(-)$ \\
\hline $12^{c}$ & $\mathrm{O}_{2} \mathrm{~N}-$ & & 100 & $-(99)$ \\
\hline
\end{tabular}

Reaction conditions: 1A $0.005 \mathrm{mmol}$, PhI $5 \mathrm{mmol}$, phenylacetylene 6 $\mathrm{mmol}, \mathrm{Et}_{3} \mathrm{~N} 7.5 \mathrm{mmol}, \mathrm{CO} 1.0 \mathrm{MPa}$, DMF $3 \mathrm{~mL}, 90^{\circ} \mathrm{C}, 1.5 \mathrm{~h}$.

a The isolated products were characterized by ${ }^{1} \mathrm{H}$ and ${ }^{13} \mathrm{C}$ NMR spectroscopy.

${ }^{\mathrm{b}}$ Determined by GC and GC-MS and the number in parentheses is the yield of Sonogashira reaction products.

c $1.0 \mathrm{MPa}$ of $\mathrm{N}_{2}$ pressure instead of $\mathrm{CO}$. 
Table 4

Recyclability of $\mathbf{2 A}$ in [Bmim] $\mathrm{PF}_{6}$ for carbonylative Sonogashira coupling of iodobenzene with phenylacetylene.

\begin{tabular}{lccc}
\hline Run & Conv. ${ }^{\text {a }}(\%)$ & Sel. $^{\text {a }}(\%)$ & TOF $\left(\mathrm{h}^{-1}\right)$ \\
\hline 1 (fresh) & 85 & 96 & 544 \\
2 & 70 & 99 & 462 \\
3 b & 65 & 99 & 429 \\
4 & 71 & 96 & 455 \\
5 & 63 & 98 & 412 \\
6 b & 63 & 99 & 416 \\
7 & 64 & 95 & 405 \\
8 & 62 & 98 & 405 \\
\hline
\end{tabular}

Reaction conditions: $\mathrm{PhI} 5 \mathrm{mmol}$, phenylacetylene $6 \mathrm{mmol} \mathrm{Et}_{3} \mathrm{~N} 7.5$ mmol, $p(\mathrm{CO})=1.0 \mathrm{MPa},[\mathrm{Bmim}] \mathrm{PF}_{6} 3 \mathrm{~mL}, 90^{\circ} \mathrm{C}, 1.5 \mathrm{~h}$.

a Determined by GC analysis.

b The slurry mixture was washed with water to remove the accumulated ammonium salt from the hydrophobic IL phase.

solvent $[\mathrm{Bmim}] \mathrm{PF}_{6}$, which immobilized the $\mathrm{Pd}$ complex catalyst to aid recovery and recycling (Table 4). Because of the mass-transfer limitation in the organic-IL biphasic reaction system, the reaction time was prolonged to $1.5 \mathrm{~h}$ during the recycling experiments. Ionic complex $2 \mathrm{~A}$ was tightly locked in the IL phase; there was no loss of Pd detected by ICP-AES analysis of the combined organic phase after eight runs. The accumulated slurry of ammonium salts in [Bmim] $\mathrm{PF}_{6}$ formed after scavenging acid by $\mathrm{Et}_{3} \mathrm{~N}$ could be removed by water to leave the clear IL phase for the next run because of the hydrophobicity of [Bmim] $\mathrm{PF}_{6}$ (entries 3 and 6 in Table 4). However, the TOFs of the 2A-[Bmim] $\mathrm{PF}_{6}$ system gradually decreased because of the unavoidable deactivation and mechanical loss of the catalyst after multiple reaction cycles.

\section{Conclusions}

After the introduction of positive charges, Pd complex 2A exhibited not only changes in complex configuration and structural stability, but also relatively lower catalytic efficiency toward the carbonylative Sonogashira reaction $(\mathrm{TOF}=2960$ $\left.\mathrm{h}^{-1}\right)$. Compared with $\mathrm{PdCl}_{2}\left(\mathrm{PPh}_{3}\right)_{2}$ and $\mathbf{2 A}$ with structural similarity, 1A ligated by $\mathbf{L 1}$ containing three types of the coordinating sites ( $\mathrm{P}, \mathrm{N}$, and $\mathrm{S}$ donor atoms) exhibited the highest catalytic performance $\left(\mathrm{TOF}=3560 \mathrm{~h}^{-1}\right.$ ), indicating the importance of the weak, reversible $\mathrm{N}$ - and S-ligation to the $\mathrm{Pd}$ center through intermolecular coordination in protecting the active $\mathbf{P d}$ catalyst. It was also found that $\mathbf{2 A}$ in [Bmim] $\mathrm{PF}_{6}$ could be recycled eight times without detectable metal leaching.

\section{References}

[1] A. S. Karpov, E. Merkul, F. Rominger, T. J. J. Müller, Angew. Chem. Int. Ed., 2005, 44, 6951-6956.

[2] C. J. Forsyth, J. Y. Xu, S. T. Nguyen, I. A. Samdal, L. R. Briggs, T. Rundberget, M. Sandvik, C. O. Miles, J. Am. Chem. Soc., 2006, 128, 15114-15116

[3] L. F. Tietze, R. R. Singidi, K. M. Gericke, H. Bockemeier, H. Laatsch, Eur. J. Org. Chem., 2007, 5875-5878.

[4] Z. L. Li, J. H. Liu, Z. W. Huang, Y. Yang, C. G. Xia, F. W. Li, ACS Catal., 2013, 3, 839-845.

[5] D. A. Alonso, C. Nájera, M. C. Pacheco, J. Org. Chem., 2004, 69, 1615-1619.

[6] B. M. Wang, M. Bonin, L. Micouin, J. Org. Chem., 2005, 70, 6126-6128.

[7] L. Chen, C. J. Li, Org. Lett., 2004, 6, 3151-3153.

[8] K. Y. Lee, M. J. Lee, J. N. Kim, Tetrahedron, 2005, 61, 8705-8710.

[9] S. J. Yim, C. H. Kwon, D. K. An, Tetrahedron Lett., 2007, 48, 5393-5395.

[10] T. Kobayashi, M. Tanaka, J. Chem. Soc., Chem. Commun., 1981, 333-334.

[11] X. F. Wu, H. Neumann, M. Beller, Chem. Soc. Rev., 2011, 40, 4986-5009.

[12] C. H. Bai, S. P. Jian, X. F. Yao, Y. W. Li, Catal. Sci. Technol., 2014, 4, 3261-3267.

\section{Graphical Abstract}

Chin. J. Catal., 2016, 37: 405-411 doi: 10.1016/S1872-2067(15)61022-1

Ionic palladium complex as an efficient and recyclable catalyst for the carbonylative Sonogashira reaction

Da Yang, Dongliang Wang, Huan Liu, Xiaoli Zhao, Yong Lu, Shijun Lai *, Ye Liu*

East China Normal University
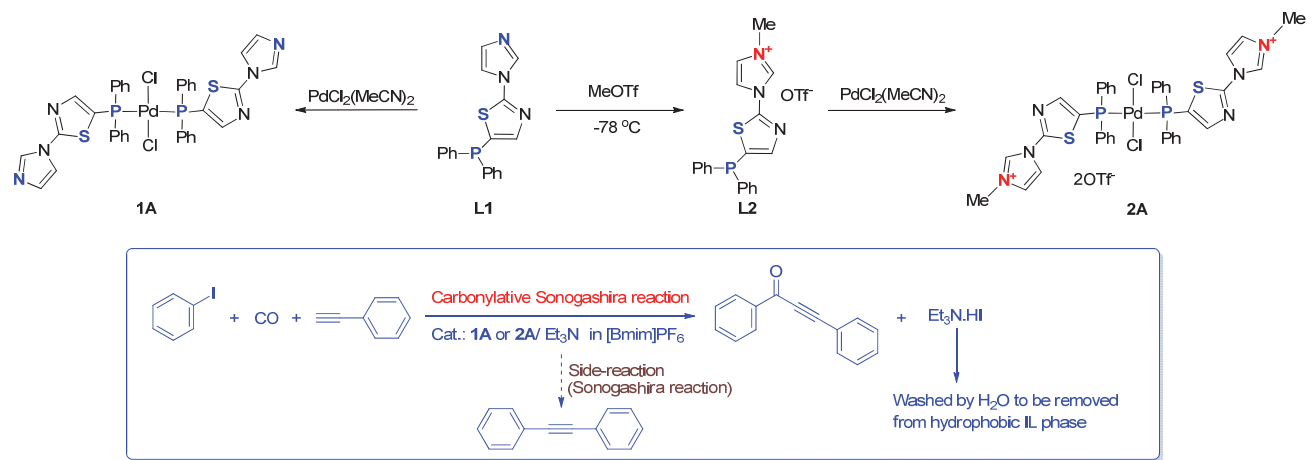

An ionic palladium complex was prepared through complexation of bis(acetonitrile)palladium(II) chloride with an ionic phosphine as an efficient and recyclable catalyst for the carbonylative Sonogashira reaction. 
[13] Md. T. Rahman, T. Fukuyama, N. Kamata, M. Sato, I. Ryu, Chem. Commun., 2006, 2236-2238.

[14] W. Y. Hao, J. C. Sha, S. R. Sheng, M. Z. Cai, J. Mol. Catal. A, 2009, 298, 94-98.

[15] P. Braunstein, F. Naud, Angew. Chem. Int. Ed., 2001, 40, 680-699.

[16] C. R. R Gan, Z. L. Liu, S. Q. Bai, K. S Ong, T. S. A. Hor, Dalton Trans., 2014, 43, 1821-1828.

[17] S. Yokota, K. Tsujimoto, S. Hayashi, F. Pointillart, L. Ouahab, H. Fujiwara, Inorg. Chem., 2013, 52, 6543-6550.

[18] C. W. Machan, A. M. Lifschitz, C. L. Stern, A. A. Sarjeant, C. A. Mirkin, Angew. Chem. Int. Ed., 2012, 51, 1469-1472.

[19] R. Lindner, B. van den Bosch, M. Lutz, J. N. H. Reek, J. I. van der Vlugt, Organometallics, 2011, 30, 499-510.

[20] R. Grigg, S. P. Mutton, Tetrahedron, 2010, 66, 5515-5548.

[21] A. Brennführer, H. Neumann, M. Beller, Angew. Chem. Int. Ed., 2009, 48, 4114-4133.

[22] J. R. Harjani, T. J. Abraham, A. T. Gomez, M. T. Garcia, R. D. Singer, P. J. Scammells, Green Chem., 2010, 12, 650-655.

[23] T. E. Kunene, P. B. Webb, D. J. Cole-Hamilton, Green Chem., 2011, $13,1476-1481$.
[24] C. Kolbeck, N. Paape, T. Cremer, P. S. Schulz, F. Maier, H. P. Steinrueck, P. Wasserscheid, Chem. Eur. J., 2010, 16, 1208312087.

[25] P. Wasserscheid, H. Waffenschmidt, P. Machnitzki, K. W. Kottsieper, O. Stelzer, Chem. Commun., 2001, 451-452.

[26] R. P. J. Bronger, S. M. Silva, P. C. J. Kamer, P. W. N. M. van Leeuwen, Chem. Commun., 2002, 3044-3045.

[27] J. Zhang, Y. Y. Wang, X. L. Zhao, Y. Liu, Eur. J. Inorg. Chem., 2014, 975-985.

[28] Y. Canac, N. Debono, C. Lepetit, C. Duhayon, R. Chauvin, Inorg. Chem., 2011, 50, 10810-10819.

[29] S. J. Lai, Y. Q. Li, H. Zhang, X. L. Zhao, Y. Liu, Catal. Commun., 2015, $58,169-173$.

[30] D. W. Allen, B. F. Taylor, J. Chem. Soc., Dalton Trans., 1982, 51-54.

[31] A. Suárez, M. A. Méndez-Rojas, A. Pizzano, Organometallics, 2002, 21, 4611-4621.

[32] B. Milde, D. Schaarschmidt, T. Rüffer, H. Lang, Dalton Trans., 2012, 41, 5377-5390.

[33] R. Oilunkaniemi, R. S. Laitinen, M. S. Hannu-Kuure, M. Ahlgrén, J. Organomet. Chem., 2003, 678, 95-101.

\title{
高效可循环离子型钯配合物催化羰化Sonogashira反应
}

\author{
杨 妲, 王栋梁, 刘 欢, 赵小莉, 路 勇, 赖时军\#, 刘 眊*
}

华东师范大学化学与分子工程学院, 上海市绿色化学与化工绿色化重点实验室, 上海200062

摘要: 炔酮类化合物作为一类具有生物活性的分子, 是天然产物全合成中构建杂环类化合物的重要中间体. 炔酮类化合物的传统 合成方法是通过过渡金属催化金属有机炔烃和酰氯的交叉偶联, 但存在酰氯本身稳定性和底物官能团耐受力较差的缺点. 近年 来, 钯催化的羰化Sonogashira反应(末端炔烃和芳基卤化物与 $\mathrm{CO}$ 的偶联反应)成为合成炔酮类化合物更为直接和有效的方法, 其中 与钯中心原子配位的配体的电子效应和空间效应可显著调控钯配合物的催化性能. 但均相钯催化的羰化Sonogashira反应体系存 在催化剂流失、分离困难和难以循环使用的问题.

我们以2-(1-咪唑基)噻唑为母体分子, 合成了具有 $\mathrm{P}, \mathrm{S}, \mathrm{N}$ 杂合配体特征的配体L1, 同时将配体L1通过与MeOTf的季铵化反应得 到相应的离子型膦配体 L2. 在此基础上, 利用 L1 和 L2 与过渡金属中心的配位作用合成相应的钯配合物 $1 \mathrm{~A}$ 和 $2 \mathrm{~A}$. 由于 $\mathrm{L1}$ 和 L2 中 含有多种不同配位能力的配体(P-配体, S-配体和/或N-配体), 故通过 N/S 杂原子对Pd-中心原子的协同弱配位作用, 可以调变相应 钯配合物对羰化Sonogashira反应的催化性能. 另外, $2 \mathrm{~A}$ 中具有强吸电子效应的正电荷的存在, 使其结构和催化性能也必然不同于 中性配合物 $1 \mathrm{~A}$.

实验结果表明, 在温和的反应条件 $\left(90^{\circ} \mathrm{C}, 1 \mathrm{~h}, \mathrm{CO}\right.$ 压强1.0 MPa)下, 对于碘苯和苯乙炔的羰化Sonogashira偶联反应, $\mathbf{1 A}$ 体现出 优于 2A 的催化性能, TOF值达到 $840 \mathrm{~h}^{-1}$; 但反应温度提高到 $120^{\circ} \mathrm{C}$ 时, $\mathbf{1 A}$ 的 TOF 高达 $3560 \mathrm{~h}^{-1}, \mathbf{2 A}$ 的 TOF为 $2960 \mathrm{~h}^{-1}$. 与 $\mathbf{L 1}$ 的 ${ }^{2} \mathrm{~J}_{\mathrm{P}-\mathrm{Se}}=$ $744 \mathrm{~Hz}$ 相比, $\mathbf{L} 2$ 的 ${ }^{2} J_{\mathrm{P}-\mathrm{Se}}=768 \mathrm{~Hz}$, 说明 $\mathbf{L} 2$ 中具有吸电子效应的正电荷的存在降低了相应P $\mathrm{P}$ 原子的 $\sigma$ 给电子能力 $\left({ }^{2} J_{\mathrm{P}-\mathrm{Se}}\right.$ 数值越大, 相 应膦配体的 $\sigma$ 给电子能力越弱); 同时, $1 \mathrm{~A}$ 中具有弱配位能力的N配体的缺失削弱了配体对Pd活性中心的稳定作用. 在底物普适性 研究中发现, 4-硝基澳苯在相同反应条件下几乎得不到羰化Sonogashira偶联产物. 而将反应体系中的 CO换为同样压强下的 $\mathrm{N}_{2}$, 却 可以顺利实现Sonogashira偶联反应. 我们推测, 在 $\mathrm{CO}$ 氛围下形成的 $\mathrm{Pd}^{0}-\mathrm{CO}$ 活性物种 (与 $\mathrm{N}_{2}$ 氛围下形成的 $\mathrm{Pd}^{0}$ 活性物种相比)具有相 对较低的对底物的氧化加成能力.

离子型钯配合物 $\mathbf{2 A}$ 的优势在于, 当将其与室温离子液体 $\left[\mathrm{Bmim}^{-} \mathrm{PF}_{6}\right.$ (溶剂)结合使用, 在 $\mathbf{2 A}$ 催化碘苯与苯乙炔的羰化 Sonogashira偶联反应过程中, 循环使用8次催化性能没有明显下降.

关键词: 离子型膦配体; 钯配合物; 羊炭化Sonogashira反应; 离子液体

收稿日期: 2015-11-02. 接受日期: 2015-11-23. 出版日期: 2016-03-05.

*通讯联系人. 电话: (021)62232078; 传真: (021)62233424; 电子信箱: yliu@chem.ecnu.edu.cn

\#通讯联系人。电话: (021)62232078; 传真: (021)62233424; 电子信箱: laishijun@126.com

基金来源: 国家自然科学基金(21473058, 21273077).

本文的英文电子版由Elsevier出版社在ScienceDirect上出版(http://www.sciencedirect.com/science/journal/18722067). 